\title{
Impact of dietary practices on serum ferritin content of pregnant mothers in the Batticaloa district Sri Lanka
}

\author{
S.Amuthenie ${ }^{1}$ and R. Sivakanesan ${ }^{2}$ \\ ${ }^{1}$ Department of Agric. Chemistry, Faculty of Agriculture, Eastern University, Sri Lanka \\ ${ }^{2}$ Department of Biochemistry, Faculty of Medicine, University of Peradeniya, Peradeniya
}

\begin{abstract}
This study was carried out to evaluate the impact of the dietary practices on serum ferritin content of pregnant mothers in the Batticaloa District. A sample size of 382 pregnant mothers aged 15 - 49 years in the second trimester of gestation was randomly selected and the food consumption patterns of them were collected using pretested food frequency questionnaires and serum ferritin level were measured by ELISA method. Data were analyzed using SPSS and MINITAB. Polynomial regression analysis was done to identify the best frequency of consumption foods that increase the serum ferritin level. The mean serum ferritin level of the mothers was $27.76 \pm 8.54 \mathrm{ng} / \mathrm{mL}$. Around $35.3 \%$ had low serum ferritin ( $<15 \mathrm{ng} / \mathrm{mL})$. Serum ferritin level was influenced by increasing frequency of consumption of beef curry $\left(r=0.18^{* *}\right.$, $p=0.001)$, beef roast $\left(r=0.15^{* *}, p=0.003\right)$, mutton $\left(r=0.122^{*}, p=0.017\right)$, prawns $(r=$ $\left.0.114^{*}, p=0.026\right)$, mango $(r=0.154 * *, p=0.003)$, pomegranate $\left(r=0.118^{*}, p=0.021\right)$, water melon $(r=0.107, p=0.036)$, lettuce $(r=0.136 * *, p=0.008)$, bottle gourd $(r=0.139 * *$, $p=0.007)$, green leafy vegetable $\left(r=0.106^{*}, p=0.038\right)$., dhal $\left(r=0.221^{* *}, p=0.000\right)$ and soya meat ( $\left.r=0.14^{* *}, p=0.006\right)$ It is important to create awareness about the nutritional value of foods and nutrition counseling to women of reproductive age to minimize iron deficiency and iron deficiency anaemia.
\end{abstract}

Key words: Serum ferritin, dietary practices, pregnant mothers

\section{INTRODUCTION}

Nutrition during pregnancy is a significant public health concern because a suboptimal diet impact negatively on the health of the mother, foetus and the new born. Lack of diet diversity has been identified by some studies to be a severe problem among poor populations in the developing world, whose diets are predominantly starchy staples and the consumption of animal products, seasonal fruits and vegetables are generally absent or minimal (Becquey Capon and MartinPrével, 2009; Arimond and Ruel, 2004). Those most likely to suffer from deficiencies include infants and young children, adolescent girls and women of reproductive age (Arimond et al., 2010; Becquey, Capon and Martin-Prével, 2009).
These vulnerable populations have been found to switch to cheaper foods that will give a feeling of fullness without regard to how nutritious the foods are (Brinkman et al., 2009). Poor nutrient intake affects maternal health and the health of the infant. For example, inadequate intake of iron during pregnancy can lead to maternal anaemia and increased risk of maternal mortality if the anaemia is severe (Cheng et al., 2009). Worldwide, anemia contributes to 20 percent of all maternal deaths and is responsible for 40 to 60 percent of maternal deaths in non industrialized countries (Karaoglu et al., 2010; Saha et al., 2007). It is estimated that anaemia accounts for 3.7 percent and 12.8 percent of maternal deaths during pregnancy and childbirth in Africa and Asia, respectively (Gautam et al., 2008).

44 
Pattern of food consumption varies invariably among pregnant mothers residing in urban and rural areas because rural women adhere to food taboos during pregnancy and avoid some foods like lamb, eel, rabbit, beef and duck more than the urban women (Zerfu et al., 2016). In a country like Sri Lanka where wide variations are noticeable in socioeconomic status as well as in diet, the prevalence of iron deficiency anaemia could show variations in different geographical and demographic subgroups. Since iron deficiency anaemia (IDA) is a major contributory factor for maternal morbidity as well as mortality, the national program caring for the antenatal women should be capable of providing satisfactory care. Based on Nutrition and Food Security Assessment (NFSA) in 2009, the prevalence of anaemia among pregnant women was highest in the urban sector $(19.3 \%)$ and the lowest in the estate sector $(8.3 \%)$. Inter district comparisons had indicated that Colombo Municipal Council had the highest prevalence (28.6\%). Anuradhapura (25\%), Badulla (21.7\%), Ratnapura (21.4\%) and Hambantota (20\%) were the other districts with prevalence of anaemia higher than the national level. IDA in Sri Lanka was estimated to be around 29\% (Palihawadana et al, 2014).

In the Batticaloa District, due to the internal conflict over the last 30 years, there is an absence of consistent information on nutritional status of pregnant mothers, especially on iron deficiency anemia. Therefore, there is a need for an up-dated data on this significant health issue in this region in order to overcome the problem of iron deficiency anaemia. As a result this study was aimed to determine the iron status of pregnant women in Batticaloa District by using serum ferritin level and to find out the influence of dietary practices during pregnancy on their serum ferritin level among pregnant women in the Batticaloa District.

\section{METHODOLOGY}

\section{Study Design, location and Sampling}

The study was carried out during April 2014 to March 2015 on a population based cross sectional study. Seven divisional secretariat divisions namely Manmunai North, Kattankudy, Manmunai South West, Manmunai West, Eravur Town, Oddamavady and Koralapattu North in the Batticaloa District were randomly selected for this study. Manmunai South West, Manmunai West and Koralaipattu North were considered as Tamil areas according to the 2012 statistics, the people living in those areas are predominately Tamils. Likewise Kattankudy, Eravur town and Oddamavady are predominately occupied by Muslims and the Manmunai North divisional secretariat has both Tamils and Muslims population (Statistical hand book of Batticaloa District, 2012). The study population consisted of pregnant mothers attending the antenatal clinics (ANC) in the selected Divisional Secretariat areas and according to the Cochran's (1977) sampling technique, the sample size of this survey covered a representative sample size of 382 at $95 \%$ confidence level. The sampling frames for the clinics were obtained from the Regional Department of health services (RDHS), Batticaloa. The selected subjects were informed about the study and those who were willing to participate in the study were screened by measuring their Erythrocyte Sedimentation Rate (ESR) to determine whether they were having any subclinical infections. A detailed consent form containing the description of the study and the information about the blood collection was given to the subjects who were free from any infections and they were further explained about the nature of the study. Finally 382 apparently healthy pregnant mothers aged 15 to 49 years in the second trimester were selected from the seven Divisional Secretariat divisions. The study was approved by the Ethical Committee of the Faculty of Health Care Science, 
Eastern University of Sri Lanka (EUSL/FHCS/ERC/2013/08). An interview with participating mother was conducted individually in the local language (Tamil) with duration of 20 to 30 minutes. Data on frequency of consumption of food items were estimated, using the pretested food frequency questionnaire containing the list of food items and the frequency of consumption. Fasting venous blood $(5 \mathrm{ml})$ was collected from subjects by venipuncture after an overnight (12hrs) fast. Blood was collected at the antenatal clinics by the nursing officer in-charge for the clinics. Collected blood was allowed to clot and then centrifuged at $3000 \mathrm{rpm}$ for 5 minutes using a bench top centrifuge (Gemmy, Taiwan) to separate the serum. Serum was analyzed for ferritin content by using ELISA method. Processed data was analyzed using Statistical Package for Social Sciences (SPSS) and MINITAB. Descriptive statistics were used to get the percentages and frequencies of variables used in this study.

\section{RESULT AND DISCUSSION}

\section{Socio economic characteristics of pregnant mothers}

The age range of the mothers included in the study was from 15 to 49 years with the mean age of 26.6years (SD \pm 5.77 ). In terms of ethnicity $56 \%$ were Tamils and $44 \%$ were Muslims. Family size of the pregnant mothers ranged from 2 to 6 with the mean family size of 3 ( $\mathrm{SD} \pm 1.02$ ). The pregnant mothers were involved in a wide range of occupation such as government job, agricultural farming and business. Majority $(58.2 \%)$ of them were housewives, $17 \%$ of them earned an income through business (groceries, tailoring and selling fish, vegetables and other farm products), $12.3 \%$ were government servants (teachers, labourers in the government sector, nurses, management assistants), $7.6 \%$ were engaged in agricultural farming, while 4.9 $\%$ were involved in other forms of occupation. This study revealed that $39.3 \%$ of the mothers belonged to the family income group of Rs. 5000-15000, around $25 \%$ of families earned Rs. 15000-25000 per month, $8.1 \%$ earned between Rs. $25000-35000,2.4 \%$ were in the range of Rs. 35000-50000 and the rest of them were earning more than Rs. 50000.

\section{Serum ferritin level of pregnant mothers in the district}

The mean serum ferritin concentration was $27.76 \mathrm{ng} / \mathrm{mL} \quad(\mathrm{SD} \pm 28.54)$ with the minimum and maximum values of 0.17 $\mathrm{ng} / \mathrm{mL}$ and $257.85 \mathrm{ng} / \mathrm{mL}$ respectively. The results revealed that $35.3 \%$ had ferritin concentration below the required minimum $(<15 \mathrm{ng} / \mathrm{mL})$ while $63.9 \%$ had normal serum ferritin concentration (15$150 \mathrm{ng} / \mathrm{mL})$ and only $0.8 \%$ had a concentration above the normal range (>150ng/mL) indicating a significant percentage of mothers were with depleted iron stores (35.3\%). Similarly a study conducted in south eastern Brazil by Pavia et al., (2007) found that $30.5 \%$ of pregnant mothers were iron deficient. Serum ferritin concentration is a reliable indicator of the status of iron stores and is the most specific indicator of depleted iron stores (Kiss, 2014).

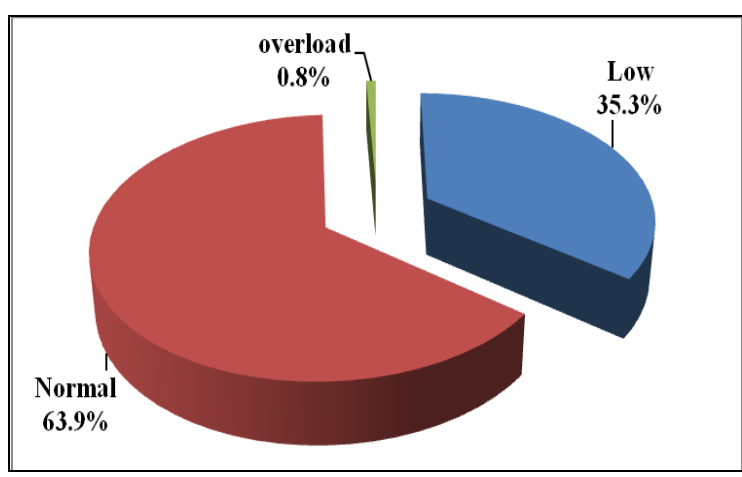

Figure 1: Serum ferritin concentrations in pregnant mothers in the Batticaloa district 
Relationship between the serum ferritin content and frequency of consumption of cereals, grains and their value added products

Table 1 depicts the relationship between the serum ferritin content and the frequency of consumption of cereals, grains and their value added products. According to Spearman's correlation analysis, frequency of consumption of cereals, grains and their value added products except brown rice did not influence the serum ferritin level of the pregnant mothers. This could be the reason for the consumption of brown rice with other iron rich food item because the iron content of brown rice is low $(1 \mathrm{mg} / 100 \mathrm{~g})$. The consumption of other iron rich food items such as meat, green leafy vegetables, dhal, soya meat, etc along with brown rice may positively influence the iron content of the pregnant mothers. Similarly, Asakura et al., (2009) also reported no association between iron status and cereal and pulse intake in young Japanese women and in Australia, Leonard et al., (2014) found no association between iron status (serum ferritin, hemoglobin or soluble transferrin: serum ferritin index) and intake of baked beans, soy beans, other beans, iron fortified breakfast cereals, rice, or pasta but Cade et al., (2005) reported that white and whole meal bread, cereals and legumes consumption by Spanish women and fortified breakfast cereals consumption by women aged 35 to 69 years living in the UK were negatively associated with serum ferritin concentrations.

Table 1: Relationship between the serum ferritin content and frequency of consumption of cereals, grains and their value added products

\begin{tabular}{lcc}
\hline Food items & Spearman's correlation (r) & P value \\
\hline Corn flakes & 0.054 & 0.289 \\
Noodles & 0.013 & 0.798 \\
Pittu & 0.73 & 0.155 \\
String hopper & 0.027 & 0.598 \\
Hopper & 0.02 & 0.693 \\
Rotty & 0.04 & 0.438 \\
Green gram & 0.009 & 0.857 \\
Chick pea & 0.055 & 0.284 \\
White rice & 0.054 & 0.292 \\
Brown rice & $0.106^{*}$ & 0.039 \\
Bread & 0.093 & 0.07 \\
Cream cracker & 0.82 & 0.11 \\
\hline
\end{tabular}

* Superscripts are significantly different

Frequency of consumption of brown rice showed significant positive correlation $\left(\mathrm{r}=0.106^{*}, \mathrm{p}=0.039\right)$ with the serum ferritin level of the mothers (Table 1) but the frequency of consumption had no significant effect [Duncan Multiple Range Test (DMRT) p>0.05] in the ferritin level of the mothers. The mean serum ferritin level increased with increasing frequency of consumption of brown rice but the 
differences were not significant. The mean ferritin level was highest among the subjects who consumed brown rice 5-6 times/week or more $(39.21 \mathrm{ng} / \mathrm{mL})$. The variations in the mean values may be influenced by some other foods such as meat, green leafy vegetables, dhal, soya meat intake because brown rice contains only $1 \mathrm{mg}$ of iron per $100 \mathrm{~g}$ (Wikramanayake, 2002).

\section{Relationship between serum ferritin content and frequency of consumption of meat and fish in the district}

The serum ferritin content increased significantly among pregnant mothers with increasing frequency of consumption of beef roast $\left(\mathrm{r}=0.15^{* *}, \mathrm{p}=0.003\right)$, beef curry $\left(\mathrm{r}=0.18^{* *}, \mathrm{p}=0.001\right)$, mutton

$(\mathrm{r}=0.122 *, \mathrm{p}=0.017)$ and prawn $(\mathrm{r}=$ $\left.0.114^{*}, \mathrm{p}<0.05\right)$ (Table 2).

Table 2: Correlation between serum ferritin content and frequency of consumption of meat and fish

\begin{tabular}{lcc}
\hline Food items & Spearman's correlation $(\mathbf{r})$ & P value \\
\hline Beef roast & $0.15^{* *}$ & 0.003 \\
Beef curry & $0.18^{* *}$ & 0.001 \\
Mutton & $0.122^{*}$ & 0.017 \\
Chicken curry & 0.022 & 0.669 \\
Fried fish & 0.067 & 0.189 \\
Fish curry & 0.044 & 0.387 \\
Canned fish & 0.002 & 0.97 \\
Prawns & $0.114^{*}$ & 0.026 \\
\hline \multicolumn{2}{c}{$*, * *$ superscripts are significantly different }
\end{tabular}

Mothers who consumed beef curry and beef roast had low serum ferritin than pregnant mothers who never consumed beef curry and beef roast. The mean serum ferritin content of subjects who never consumed beef curry was significantly higher only with those who consumed once a week (Table 3). Among beef consumers more than $90 \%$ were Muslims and only about $10 \%$ were Tamils. Because of the religious barriers majority of the Tamil mothers did not consume beef but they used to take other iron rich food such as fish $(2.5 \mathrm{mg} / 100 \mathrm{~g})$, chicken $(1.5 \mathrm{mg} / 100 \mathrm{~g})$, mutton $(2.2 \mathrm{mg} / 100 \mathrm{~g})$, soya meat $(8 \mathrm{mg} / 100 \mathrm{~g})$ and green leafy vegetables $(26.8 \mathrm{mg} / 100 \mathrm{~g})$ for their iron requirement. The serum ferritin content was significantly higher in mothers who consumed mutton 2 to 4 times per week $(32.77 \mathrm{ng} / \mathrm{ml})$ compared to mothers who never consumed mutton $(22.92 \mathrm{ng} / \mathrm{ml})$. The mean serum ferritin level was progressively higher with increased frequency of consumption of prawns but no statistically significant differences were observed between the groups. ANOVA showed no significant difference in serum ferritin level and frequency of consumption of beef curry ( $\mathrm{p}=0.486)$, beef roast $(\mathrm{p}=0.686)$, mutton $(\mathrm{p}=0.908)$ and prawns $(\mathrm{p}=0.984)$. The result showed that mean ferritin level increased with the frequency of consumption of beef curry, mutton and prawns (Tables 3). Similar result was found in Women in the United States who consumed red meat had higher serum ferritin and hemoglobin concentrations compared to lacto-ovo vegetarians, or those consuming fish or poultry as their main protein source (Beck et al., 2014). 
Table 3: Mean values of serum ferritin of meat and fish consumers and non-consumers

\begin{tabular}{|c|c|c|}
\hline Food items & Ferritin Mean & SD \\
\hline \multicolumn{3}{|c|}{ Beef curry } \\
\hline Never consumed & $32.49^{\mathrm{a}}$ & 18.35 \\
\hline Occasional & $20.95^{\mathrm{ab}}$ & 19.01 \\
\hline Once a week & $21.46^{\mathrm{b}}$ & 14.98 \\
\hline 2-4 times per week & $25.12^{\mathrm{ab}}$ & 14.63 \\
\hline \multicolumn{3}{|c|}{ Beef roast } \\
\hline Never consumed & $31.51^{\mathrm{a}}$ & 23.08 \\
\hline Occasional & $23.11^{\mathrm{ab}}$ & 17.26 \\
\hline Once a week & $18.14^{\mathrm{b}}$ & 14.70 \\
\hline 2-4 times/ week & $21.21^{\mathrm{ab}}$ & 13.91 \\
\hline 5-6 times/ week & $25.62^{\mathrm{ab}}$ & 18.96 \\
\hline Daily & $27.92^{\mathrm{ab}}$ & 7.61 \\
\hline \multicolumn{3}{|c|}{ Mutton } \\
\hline Never consumed & $22.92^{\mathrm{a}}$ & 18.11 \\
\hline Occasional & $27.01^{\mathrm{ab}}$ & 36.03 \\
\hline Once a week & $29.78^{\mathrm{ab}}$ & 25.07 \\
\hline 2-4 times/ week & $32.77^{\mathrm{b}}$ & 36.88 \\
\hline \multicolumn{3}{|c|}{ Prawns } \\
\hline Never consumed & $24.38^{\mathrm{a}}$ & 25.63 \\
\hline Occasional & $28.93^{\mathrm{a}}$ & 27.01 \\
\hline Once a week & $29.04^{\mathrm{a}}$ & 32.53 \\
\hline 2-4 times/ week & $36.29^{\mathrm{a}}$ & 36.04 \\
\hline 5-6 times/ week & $37.62^{\mathrm{a}}$ & 25.56 \\
\hline
\end{tabular}

\section{Relationship between serum ferritin content and the frequency of consumption of milk, milk products and egg.}

Spearman's correlation analysis revealed that the consumption pattern of milk, milk products and egg did not significantly influence the serum ferritin content of the mothers (Table 4) as it's obvious that the iron content of milk and milk products is very low therefore is unlikely to affect the serum ferritin concentration. Similarly other studies, also have found no association between iron status and dairy products or milk intake (Brussard et al., 1997; Asakura et al., 2009; Pynaert, et al 2009; Blanco- Rojo et al., 2014 and Rigas et al., 2014), but Galan et al (1998) stated that iron status of women was negatively associated with consumption of dairy products. Leonard et al., (2014) reported the serum ferritin concentrations to be negatively associated with frequency of egg consumption. However, other studies found no association between iron status and egg consumption (Brussard et al., 1997; Asakura et al., 2009; Blanco- Rojo et al., 2014; Rigas et al., 2014). 
Table 4: Correlation between serum ferritin content and frequency of consumption of milk, milk products and egg

\begin{tabular}{lcc}
\hline Food items & Spearman's correlation & P value \\
\hline Milk & .02 & .696 \\
Yoghurt & .062 & .227 \\
Curd & .009 & .854 \\
Butter & .064 & .211 \\
Ghee & .08 & .121 \\
Egg & .036 & .484 \\
Cheese & .052 & .315 \\
Margarine & .028 & .587 \\
\hline
\end{tabular}

\section{Relationship between serum ferritin content and the frequency of consumption of beverages}

The frequency of consumption of beverages except viva did not influence the serum ferritin level of the pregnant mothers (Table 5). Viva contains $18.1 \mathrm{mg} / 100 \mathrm{~g}$ of iron (Wikramanayake, 2002 and manufacturer's label) and mothers reported that they added one heaped table spoon $(\approx 25 \mathrm{grams})$ of viva to a glass $(200 \mathrm{ml})$ of hot milk to prepare the viva drink. Several studies found no relationship between tea and coffee intake and iron status (Brussard et al., 1997; Galan et al., 1998; Heath et al., 2001; Mennen et al., 2007 and Rigas et al., 2014) similar to the results obtained in the present study.

Table 5: Relationship between serum ferritin content and frequency of consumption of beverages

\begin{tabular}{lcc}
\hline Food items & Pearson correlation (r) & P value \\
\hline Milk tea & 0.094 & 0.065 \\
Coffee & -0.012 & 0.819 \\
Viva & $0.109^{*}$ & 0.033 \\
Soft drink & 0.062 & 0.226 \\
Fruit cordial & 0.006 & 0.903 \\
Nestomalt & 0.072 & 0.159 \\
Fresh fruit juice & 0.1 & 0.051 \\
Horlicks & 0.027 & 0.6 \\
\hline
\end{tabular}

*superscripts are significantly different

According to the Spearman's correlation analysis, frequency of consumption of viva showed significant positive correlation $\left(\mathrm{r}=0.109^{*}, \mathrm{p}=0.033\right)$ with serum ferritin level of the mothers. Mothers who consumed viva daily had high serum ferritin content $(43.51 \mathrm{ng} / \mathrm{mL})$ than pregnant mothers who never consumed 
viva $(25.4 \mathrm{ng} / \mathrm{mL})$. Viva contains $18.1 \mathrm{mg} / 100 \mathrm{~g}$ of iron (Wikramanayake, 2002) and mothers reported that they added one heaped table spoon $(\approx 25$ grams $)$ of viva to a glass $(200 \mathrm{ml})$ of hot milk to prepare the viva drink. Similar to our study, several studies found no relationship between tea and coffee consumption and iron status (Brussard et al, 1997; Galan et al, 1998; Heath et al, 2001; Mennen et al, 2007 and Rigas et al, 2014).

\section{Relationship between serum ferritin content and frequency of consumption of sweets and snacks}

According to the spearman's correlation analysis frequency of consumption of sweets and snack except buns did not influence serum ferritin content (Table 6). However serum ferritin content among mothers with different patterns of consumption of buns was statistically not significant (DMRT, p>0.05) Curry buns stuffed with soya meat or chicken or fish or potato or seeni-sambol were available in the study area and possibly the stuffed items are rich in iron.

Table 6: Correlation between serum ferritin content and the frequency of consumption of sweets and snacks

\begin{tabular}{lcc}
\hline Food items & Spearman's correlation (r) & P value \\
\hline Biscuits & .019 & .711 \\
Cakes & .029 & .578 \\
Buns & $.104^{*}$ & .043 \\
Ice cream & .012 & .814 \\
Toffees & .004 & .945 \\
Sugar add cereals & .03 & .559 \\
Cocktail Mixture & .061 & .235 \\
Pea nuts & .089 & .081 \\
\hline
\end{tabular}

*, ** Superscripts are significantly different

\section{Relationship between serum ferritin content and the frequency of consumption of fruits}

With regard to the consumption of fruits, frequency of consumption of mango $(\mathrm{r}=$ $0.154 * *, \quad \mathrm{p}=0.003)$, pomegranate $(\mathrm{r}=$ $\left.0.118^{*}, \quad \mathrm{p}=0.021\right)$ and watermelon $(\mathrm{r}=0.107, \mathrm{p}=0.036)$ positively influenced the serum ferritin level of the mothers (Table 7). ANOVA was performed to find out the differences among the frequency of the consumption of mango, pomegranate and water melon. 
Table 7: Correlation between serum ferritin content and frequency of consumption pattern of fruits

\begin{tabular}{lcc}
\hline Fruit types & Spearman's correlation (r) & P value \\
\hline Apple & .02 & .693 \\
Orange & .011 & .835 \\
Banana & .045 & .378 \\
Grapes & .01 & .844 \\
Guava & .063 & .222 \\
Mango & $.154^{* *}$ & .003 \\
Pine Apple & .032 & .53 \\
Mangusteen & .061 & .238 \\
Rumbutan & .086 & .092 \\
Pomegranate & $.118^{*}$ & .021 \\
Water melon & $.107^{*}$ & .036 \\
Avacardo & .057 & .268 \\
\hline
\end{tabular}

$*, * *$ Superscripts are significantly different

The mothers who consumed mango daily had significantly higher serum ferritin level compared with mothers who never consumed mango but Frequency of consumption of watermelon and pomegranate had no significant effect on serum ferritin level (ANOVA $\mathrm{p}>0.05$ ).

Table 8: Mean values of serum ferritin of mango, pomegranate and water melon

\begin{tabular}{lcc}
\hline Food items & Ferritin Mean & SD \\
\hline Never consumed & Mango & 19.35 \\
Occasional & $21.37^{\mathrm{b}}$ & 26.43 \\
Once a week & $28.08^{\mathrm{ab}}$ & 23.44 \\
2-4 times/ week & $27.31^{\mathrm{ab}}$ & 30.15 \\
$5-6$ times/ week & $28.32^{\mathrm{ab}}$ & 26.51 \\
Daily & $28.94^{\mathrm{ab}}$ & 46.25 \\
\hline & $34.77^{\mathrm{a}}$ & \\
\hline Never consumed & Watermelon & 31.39 \\
Occasional & $30.02^{\mathrm{a}}$ & 10.09 \\
Once a week & $20.32^{\mathrm{a}}$ & 5.29 \\
2-4 times/ week & $17.07^{\mathrm{a}}$ & 11.55 \\
5-6 times/ week & $20.49^{\mathrm{a}}$ & 14.78 \\
Daily & $21.35^{\mathrm{a}}$ & 27.64 \\
\hline & $26.04^{\mathrm{a}}$ & 32.10 \\
\hline Never consumed & Pomegranate & 10.53 \\
Occasional & $29.91^{\mathrm{a}}$ & 20.27 \\
Once a week & $17.33^{\mathrm{a}}$ & 17.81 \\
2-4 times/ week & $21.70^{\mathrm{a}}$ & 27.33 \\
5-6 times/ week & $18.26^{\mathrm{a}}$ & \\
\hline
\end{tabular}

Mean with same letters are not significantly different at $\mathrm{p}=0.05$ 
Mango has high amount of vitamin $\mathrm{C}$ $(27.7 \mathrm{mg} / 100 \mathrm{~g})$ than pomegranate $(10.2 \mathrm{mg} / 100 \mathrm{~g})$ and water melon (2.5mg/100g) (Wikramanayake, 2002). The influence of mango consumption on serum ferritin level may be due to the higher level of the vitamin $\mathrm{C}$ increasing the absorption of the iron present in the food stuff.

Considering pomegranate and water melon, mean serum ferritin level was high among non-consumers than consumers because less percentage of the pregnant mothers consumed pomegranate and watermelon compared with mango consumption and of course pomegranate and water melon has low vitamin $\mathrm{C}$ content compared with mango but in contrast, Peneau et al., (2008) found no association between serum ferritin concentration and consumption of ascorbic acid-rich fruit and they suggested that diets containing a range of fruit and vegetable combinations also did not affect the serum ferritin concentration.

\section{Relationship between the serum ferritin content and the frequency of consumption of vegetables}

Among the vegetables consumed by mothers, the frequency of consumption of lettuce $\left(0.136^{* *}, \mathrm{p}=0.008\right)$, bottle gourd $\left(\mathrm{r}=0.139^{*}, \quad \mathrm{p}=007\right)$ and green leafy vegetables $(\mathrm{r}=0.106, \quad \mathrm{p}=0.038)$ significantly influenced the serum ferritin level positively (Table 9).

Mothers who consumed bottle gourd and green leafy vegetables showed adequate serum ferritin level. Lettuce consumers had low serum ferritin level compared to non-consumers. Statistically significant associations were not observed in serum ferritin level and frequency of consumption of lettuce and bottle gourd. The reason for the low consumption of lettuce in the rural areas was the less availability. The mothers consuming green leafy vegetables daily had higher serum ferritin content than those not consuming green leafy vegetables. Bottle gourd contains only $0.2 \mathrm{mg}$ iron per 100 grams and lettuce contains $1.24 \mathrm{mg}$ iron per 100 grams but other green leafy vegetables like spinach, amaranthus and moringa leaves contain $35.8 \mathrm{mg}$ per 100grams, 26.8 mg per 100grams and 4mg per 100 grams of iron respectively.

ANOVA was performed to assess the relationship between serum ferritin level and the frequency of bottle gourd and green leafy vegetable consumption. No significant relationships were observed in the frequency of bottle gourd $(\mathrm{p}=0.882)$ and leafy vegetable $(\mathrm{p}=0.053)$ consumption and serum ferritin level but the mean value of serum ferritin increased among the mothers who consumed bottle gourd and leafy vegetables with high frequency. Similarly, Peneau et al (2008) also found no significant association between serum ferritin concentration and consumption of vegetables. However higher intakes of fibre-poor vegetables juices were associated with higher serum ferritin concentrations. Romeu et al (2013) also stated that consumption of leafy green vegetable, fruits and vegetables had positive effects on the iron status in human.

In contrast, few studies reported that lower consumption of dark green leafy vegetables was significantly associated with increased risk of iron deficiency anemia (Tadesse et al., 2017; Obse et al., 2013; Karaoglu et al., 2010 and Semba and Bloem, 2002) among pregnant mothers. 
Table 9: Correlation between the serum ferritin content and the frequency of consumption of vegetables

\begin{tabular}{|c|c|c|}
\hline Food items & Spearman's correlation $(r)$ & $P$ value \\
\hline Carrot & .14 & .792 \\
\hline Spinach & .061 & .233 \\
\hline Cauliflower & .081 & .113 \\
\hline Leeks & .067 & .19 \\
\hline Onion & .006 & .905 \\
\hline Garlic & .075 & .144 \\
\hline Lettuce & $.136 * *$ & .008 \\
\hline Tomato & .05 & .333 \\
\hline Potato & .045 & .381 \\
\hline Brinjal & .018 & .732 \\
\hline Okra & .087 & .091 \\
\hline Pumpkin & .043 & .407 \\
\hline Bitter gourd & .059 & .251 \\
\hline Snake gourd & .004 & .943 \\
\hline Bottle gourd & $.139 * *$ & .007 \\
\hline Lufa & .037 & .474 \\
\hline Beetroot & .008 & .873 \\
\hline Drumstick & .03 & .564 \\
\hline Capsicum & .002 & .97 \\
\hline Sweet potato & .053 & .301 \\
\hline Manioc & .051 & .317 \\
\hline Plantain & .013 & .8 \\
\hline Banana flower & .069 & .18 \\
\hline $\begin{array}{l}\text { Green leafy } \\
\text { vegetables }\end{array}$ & $.106^{*}$ & .038 \\
\hline
\end{tabular}

$*, * *$ Superscripts are significantly different 
Table 10: Mean values of serum ferritin of lettuce, bottle gourd and leafy vegetables consumers

\begin{tabular}{lcc}
\hline Food items & Ferritin (Mean) & SD \\
\hline \multicolumn{3}{c}{ Lettuce } \\
\hline Never consumed & $31.46^{\mathrm{a}}$ & 32.57 \\
Occasional & $20.85^{\mathrm{a}}$ & 12.81 \\
Once a week & $21.54^{\mathrm{a}}$ & 11.60 \\
2-4 times/ week & $23.28^{\mathrm{a}}$ & 18.24 \\
5-6 times/ week & $22.99^{\mathrm{a}}$ & 24.12 \\
\hline \multicolumn{3}{c}{ Bottle gourd $^{\mathrm{a}}$} \\
\hline Never consumed & $23.82^{\mathrm{a}}$ \\
Occasional & $31.04^{\mathrm{a}}$ & 24.23 \\
Once a week & $27.94^{\mathrm{a}}$ & 35.83 \\
2-4 times/ week & $41.33^{\mathrm{a}}$ & 26.46 \\
\hline \multicolumn{3}{c}{ Green leafy vegetable } \\
\hline Never consumed & $21.98^{\mathrm{a}}$ \\
Occasional & $24.47^{\mathrm{a}}$ & 17.43 \\
Once a week & $23.00^{\mathrm{a}}$ & 19.35 \\
2-4 times/ week & $28.71^{\mathrm{a}}$ & 19.65 \\
5-6 times/ week & $31.42^{\mathrm{a}}$ & 25.17 \\
Daily & $38.28^{\mathrm{a}}$ \\
\hline Mean with same letters are not significantly different at $\mathrm{p}=0.05$
\end{tabular}

\section{Relationship between serum ferritin content and frequency of consumption of soya meat and dhal}

According to the table 11, consumption of soya meat $(\mathrm{r}=0.221, \mathrm{p}=0.000)$ and dhal $(\mathrm{r}=$
$0.14, p=0.006)$ significantly increased the serum ferritin content of pregnant mothers.

Table 11 Correlation between the serum ferritin content and frequency of consumption of soya meat and dhal

\begin{tabular}{ccc}
\hline & Spearman's correlation & P value \\
\hline Soya meat & $.221^{* *}$ & .002 \\
dhal & $.14^{* *}$ & .006 \\
\hline$* *$ Superscripts are significantly different
\end{tabular}

Increasing serum ferritin level among mothers by the consumption of soya meat and dhal may be due to the addition of tomatoes during preparation of food. During the questionnaire survey, most of the mothers reported that they are adding about 100grams of tomato when preparing curry from one packet of soya meat and about one fruit (medium size) to dhal curry to enhance the taste. Sharma in 2003 also reported that addition of ascorbic acid to cereals, pulses and vegetables enhance the available iron in India and also soya meat (8mg) and dhal (7.2mg) contain high amount of iron per 100 grams of edible portion. When ANOVA was performed between the serum ferritin level and the frequency of consumption of soya meat showed positive significant difference in serum ferritin level between soya meat 
consumers and non-consumers were observed. Mothers who consumed soya meat 5 to 6 times per week and daily had significantly higher level of serum ferritin than mothers who never consumed soya meat.

Table 12: Mean values of serum ferritin of soya meat and dhal consumers and non consumers

\begin{tabular}{|c|c|c|}
\hline Food items & Ferritin (Mean) & SD \\
\hline \multicolumn{3}{|c|}{ Soya meat } \\
\hline $\begin{array}{l}\text { Never } \\
\text { consumed }\end{array}$ & $19.17^{\mathrm{b}}$ & 12.98 \\
\hline Occasional & $26.46^{\mathrm{ab}}$ & 19.27 \\
\hline Once a week & $26.12^{\mathrm{ab}}$ & 13.17 \\
\hline 2-4 times/ week & $31.48^{\mathrm{ab}}$ & 35.70 \\
\hline 5-6 times/ week & $37.93^{\mathrm{a}}$ & 39.79 \\
\hline Daily & $38.01^{\mathrm{a}}$ & 36.23 \\
\hline \multicolumn{3}{|c|}{ Dhal } \\
\hline $\begin{array}{l}\text { Never } \\
\text { consumed }\end{array}$ & $22.22^{b}$ & 18.80 \\
\hline Occasional & $19.01^{\mathrm{b}}$ & 10.29 \\
\hline Once a week & $23.94^{\mathrm{b}}$ & 19.80 \\
\hline 2-4 times/ week & $26.01^{\mathrm{b}}$ & 16.36 \\
\hline 5-6 times/ week & $30.23^{\mathrm{b}}$ & 32.19 \\
\hline Daily & $52.32^{\mathrm{a}}$ & 62.21 \\
\hline
\end{tabular}

Further, ANOVA was performed to assess the relationship between serum ferritin level and the frequency of dhal consumption. Pregnant mothers who consumed dhal daily had higher serum ferritin level than other dhal consumers and non consumers as well. The mean value of serum ferritin increased among the mothers who consumed soya meat and dhal with increased frequency of consumption. Brussard et al., (1997) observed a negative correlation between vegetable protein intake and iron status and Blanco-Rojo et al., (2014) found no association between protein intake in women with normal iron status, mild iron deficiency and women close to developing iron deficiency anaemia.

\section{Relative importance of frequency of food consumption on the ferritin level of pregnant mothers}

The polynomial type of production function was used to determine the optimum serum ferritin level for the different frequency of consumption of food items. Significant relationship $(p<0.05)$ was observed between the serum ferritin level and the different frequency of consumption of some food items.

Figure 2 depicts the polynominal regression between mean ferritin level and frequency of consumption of different food items. The best response of serum ferritin level for different frequency of consumption of food items were described by the following equations. 


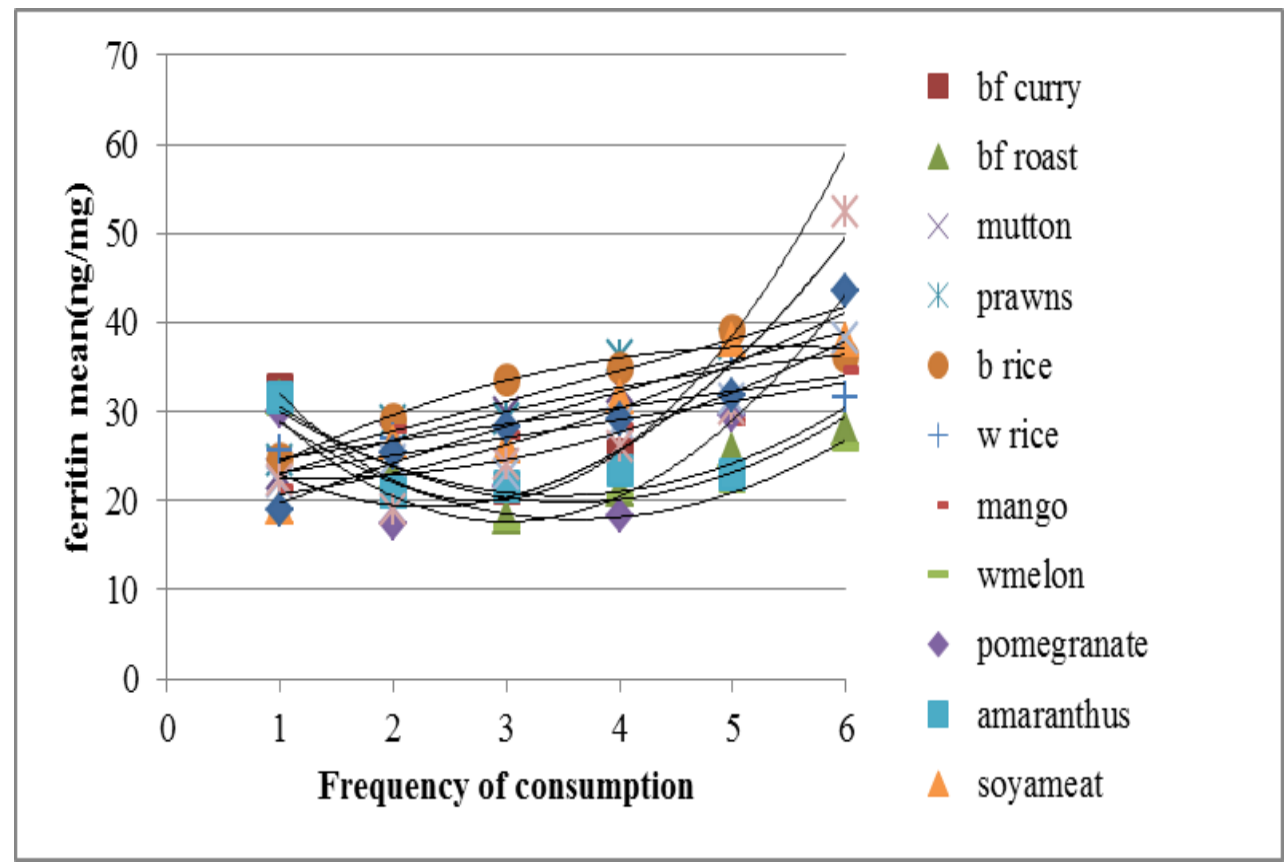

1-never, 2- occasional, 3- once/week, 4- 2-4times/week, 5-5-6 times/week, 6-daily

\section{Figure 2: Relationship between mean ferritin level and frequency of consumption of some food items}

$\begin{array}{ll}\text { Beef curry: } & \mathrm{y}=1.625 \mathrm{x}^{2}-12.785 \mathrm{x}+40.491 \\ \text { Beef roast: } & \mathrm{y}=3.799 \mathrm{x}^{2}-21.158 \mathrm{x}+49.412 \\ \text { Mutton: } & \mathrm{y}=0.575 \mathrm{x}^{2}+4.6053 \mathrm{x}+18.673 \\ \text { Prawns: } & \mathrm{y}=0.493 \mathrm{x}^{2}+3.0866 \mathrm{x}+21.455 \\ \text { Brown rice: } & \mathrm{y}=-0.6768 \mathrm{x}^{2}+7.2772 \mathrm{x}+17.77 \\ \text { Mango: } & \mathrm{y}=0.202 \mathrm{x}^{2}+1.876 \mathrm{x}+21.246 \\ \text { Water melon: } & \mathrm{y}=1.5787 \mathrm{x}^{2}-11.432 \mathrm{x}+38.623 \\ \text { Pomegranate: } & \mathrm{y}=1.8418 \mathrm{x}^{2}-17.045 \mathrm{x}+43.214 \\ \text { Amaranthus: } & \mathrm{y}=1.109 \mathrm{x}^{2}-10.746 \mathrm{x}+39.228 \\ \text { Soya meat: } & \mathrm{y}=-0.3907 \mathrm{x}^{2}+4.9514 \mathrm{x}+14.973 \\ \text { Leafy vegetables: } & \mathrm{y}=0.1688 \mathrm{x}^{2}-1.7318 \mathrm{x}+23.598 \\ \text { Dhal: } & \mathrm{y}=1.0584 \mathrm{x}^{2}-10.137 \mathrm{x}+30.944 \\ \text { Viva: } & \mathrm{y}=0.1219 \mathrm{x}^{2}+0.9936 \mathrm{x}+19.328\end{array}$

Where $\mathrm{y}=$ best frequency of consumption of particular food item, and $\mathrm{x}=$ mean serum ferritin level for particular food item $(\mathrm{ng} / \mathrm{mL})$. The optimum mean serum ferritin level of pregnant mothers for the frequency of consumption of different food items obtained from quadratic equations is between once in a week to daily. This was calculated by equalizing the first derivative of the curve to zero.
Accordingly, consumption of beef roast, prawns and pomegranate once in a week, positively influences (increase) the serum ferritin content among pregnant mothers. Likewise, consumption of beef curry and mutton 2 to 4 times in a week also increases the ferritin content while 5 to 6 times per week consumption of brown rice, mango, amaranthus, leafy vegetables and dhal and daily consumption of soya 
meat showed positive response to the ferritin content among pregnant mothers. In contrast, Rao et al (2001) found no association between the frequency of consumption of green leafy vegetables and the serum ferritin level of the pregnant mothers in India.

\section{CONCLUSIONS}

One third of the pregnant mothers had low level of serum ferritin $(<15 \mathrm{ng} / \mathrm{ml})$. It is due to the poor intake of food specially iron rich foods (meat and leafy vegetables).

The ferritin content in the serum of the pregnant women increased with the increase in frequency of consumption of meat specially beef and mutton, some fruits and vegetables and brown rice.

The serum ferritin content of the pregnant mother was progressively higher with increase in frequency of consumption of meat, especially beef and mutton, some fruits and vegetables such as mango, watermelon, pomegranate, soya meat, green leafy vegetables and dhal and brown rice. . Mothers who did not consume leafy vegetables, soya meat, mutton and dhal were more iron deficient during their second trimester of pregnancy.

Based on the findings of the study the following recommendations were made.

1. The results of the study emphasized the importance of nutrient intake during pregnancy. Therefore, proper nutrition counseling and awareness is very important to improve the nutritional status of the pregnant mothers. The health team who are responsible for the antenatal care must be educated about conveying the message regarding the importance of iron nutrition during pregnancy in a more meaningful way to the public.

2. There is a need to create awareness in the community and especially among the women of reproductive age on the problem of high prevalence of anaemia, focusing on early prevention. The high rates of anaemia may be reduced by dietary diversification and recipe modifications by using locally available food materials. Effective nutrition intervention should be directed towards pregnant mothers to improve maternal nutrition status. This can be done through promotion of community nutrition education and awareness programmes.

\section{REFERENCES}

Arimond, M., \& Ruel, M. T. (2004). Dietary diversity is associated with child nutritional status: Evidence from 11 Demographic and Health Surveys. The Journal of Nutrition. 134: p 2579-2585.

Arimond, M., Wiesmann, D., Becquey, E., Carriquiry, A., Daniels, M. C., Deitchler, M. \& Fanou Fogny. (2010). Simple food group diversity indicators predict micronutrient adequacy of women's diets in 5 diverse, resource-poor settings. Journal of Nutrition. 140(11): p 20592069.

Asakura, K., Sasaki, S., Murakami, K., Takahashi, Y., Uenishi, K., Yamakawa, M., Nishiwaki, Y., Kikuchi, Y. \& Takebayashi, T. (2009). Japan Dietetic Students' Study for Nutrition and Biomarkers Group. Iron intake does not significantly correlate with iron deficiency among young Japanese women: A crosssectional study. Public Health Nutrition. 12, p1373-1383.

Beck .K. L, Cathryn A. Conlon, Rozanne Kruger \& Jane Coad. (2014).Dietary Determinants of and Possible Solutions to Iron Deficiency for Young Women Living in Industrialized Countries: A Review. Nutrients 2014, 6(9): p 3747-3776. https://doi.org/10.3390/nu6093747 . 
Becquey, E., Capon, G., \& Martin Prével, Y. (2009). Dietary Diversity as a Measure of the Micronutrient Adequacy of Women's Diets: Results from Ouagadougou, Burkina Faso Site.Washington, DC: Food and Nutrition Technical Assistance II Project Report, Academy for Educational Development.

Blanco-Rojo, R., Toxqui, L., Lopez-Parra, A.M., Baeza-Richer, C., Perez-Granados, A.M., Arroyo-Pardo, E. \& Pilar Vaquero, M. (2014). Influence of diet, menstruation and genetic factors on iron status: A crosssectional study in Spanish women of childbearing age. Int. J. Mol. Sci., 15, p4077-4087.

Brussard, J.H., Brants, H.A.M., Bouman, M. \& Lowik, M.R.H. (1997). Iron intake and iron status among adults in the Netherlands. European Jounal of Clinical Nutrition.51: p 51-58.

Brinkman, H.J., de Pee, S., Sanogo, I., Subran, L. \& Bloem, M. W. (2009). High food prices and the global financial crisis have reduced access to nutritious food and worsened nutritional status and health. Journal of Nutrition. 140(1): p153S-161S.

Cheng, Y., Dibley, M. J., Zhang, X., Zeng, L. \& Yan, H. (2009). Assessment of dietary intake among pregnant women in a rural area of western China. Journal of BioMed Central Public Health. 9: pp 222.

Cochran, W. G. (1977). Sampling techniques (3rd ed.). New York: John Wiley \& Sons.

Galan, P., Yoon, H.C., Preziosi, P., Viteri, F., Valeix, P., Fieux, B., Brianc Àon, S., Malvy, D., Roussel, A.M., Favier, A. \& Hercberg, S. (1998). Determining factors in the iron status of adult women in the su.vi.max study.

Gautam, C. S., Saha, L., Sekhri, K. \& Saha, P. K. (2008). Iron deficiency in pregnancy and the rationality of iron supplements prescribed during pregnancy. The Medscape Journal of Medicine. 10(12): p 283.

Heath, A.L.M., Skeaff, C.M., O'Brien, S.M., Williams, S.M. \& Gibson, R.S. (2001). Can dietary treatment of nonanemic iron deficiency improve iron status? J. Am. Coll. Nutr. 2001;20:477484.

Karaoglu, L., Pehlivan, E., Egri, M., Deprem, C., Gunes, G., Genc, M. F. \& Temel, I. (2010). The prevalence of nutritional anemia in pregnancy in an east Anatolian province, Turkey. Journal of BioMed Central Public Health. 10: pp 329.

Kiss, J. E. (2014). Laboratory and genetic assessment of iron deficiency in blood donors. Clinics in laboratory medicine, 35(1), 73-91.

Leonard, A.J., Chalmers, K.A., Collins, C.E. \& Patterson, A. (2014). The effect of nutrition knowledge and dietary iron intake on iron status in young women. Appetite. 81: pp 225-231.

Mennen, L., Hirvonen, T., Arnault, N., Bertrais, S., Galan, P. \& Hercberg, S. (2007). Consumption of black, green and herbal tea and iron status in French adults. Eur. J. Clin. Nutr.61: pp 1174-1179.

Obse, N., Mossie, A. \& Gobena, T. (2013) Magnitude of anemia and associated risk factors among pregnant women attending antenatal care in Shalla Woreda, West Arsi Zone, Oromia Region, Ethiopia. Ethiopian Journal of Health Sciences.;23(2):165-73.

Paiva, A.A., Patrícia, Rondó, H.C., Regina, A. Pagliusi., Maria do R. D. O. Latorre., Maria A. A. Cardoso. \& Sheila, S. R. Gondim. (2007) Relationship between the iron status of pregnant women and their newborns, Rev. Saúde 
Pública vol.41 no.3.doi.org/10.1590/S0034 -89102007000300001.

Palihawadana, T.S., Goonewardene, I.M.R., Motha, M.B.C. \& Williams, H.A.S. (2014). Iron Deficiency Anaemia in Pregnancy: Diagnosis, Prevention and Treatment. Sri Lanka Journal of Obstetrics and Gynaecology. 36: pp 61-65.

Péneau, S., Dauchet, L., Vergnaud, A.C., Estaquio, C., Kesse-Guyot, E., Bertrais, S., Latino- Martel, P., Hercberg, S. \& Galan, P. ( 2008). Relationship between iron status and dietary fruit and vegetables based on their vitamin $\mathrm{C}$ and fiber content. Am. J. Clin. Nutr. 87: pp1298-1305.

Pynaert, I., de Bacquer, D., Matthys, C., Delanphe, J., Temmerman, M., de Backer, G. \& de Henauw, S. (2009). Determinants of ferritin and soluble transferrin receptors as iron status parameters in young adult women. Public Health Nutr.12: pp 17751782.

Rao, S., Yajnik, C.S., Kanade, A., Fall, C.H., Margetts, B.M., Jackson, A.A., Shier, R., Joshi, S., Rege, S., Lubree, H. \& Desai, B. (2001). Intake of micronutrientrich foods in rural Indian mothers is associated with the size of their babies at birth: Pune Maternal Nutrition Study. Journal of Nutrition. 131(4): pp 1217-24.

Rigas, A.S., Sorensen, C.J., Pedersen, O.B., Petersen, M.S., Thorner, L.W., Kotze, S., Sorensen, E., Magnussen, K., Rostgaard, K. \& Erikstrup, C. (2014). Predictors of iron levels in 14,737 Danish blood donors: Results from the Danish Blood Donor Study. Transfusion.54: pp 789-796.

Romeu, M., Nuria Aranda, Montserrat Giralt, Blanca Ribot, Maria Rosa Nogues \& Victoria Arija. (2013) Diet, iron biomarkers and oxidative stress in a representative sample of Mediterranean population Nutrition Journal12:102.

Saha, L., Pandhi, P., Gopalan, S., Malhotra, S., and Saha, P. K. (2007). Comparison of efficacy, tolerability, and cost of iron polymaltose complex with ferrous sulphate in the treatment of iron deficiency anemia in pregnant women. Medscape Journal of Medicine. 9(1): pp 1.

Semba, R. \& Bloem, M. (2002) The anemia of Vitamin A deficiency: Epidemiology and Pathogenesis. European Journal of Clinical Nutrition; 56(4):27181. doi: 10.1038/sj.ejen.1601320.

Sharma, K.K. (2003). Improving bioavailability of iron in Indian diets through food-based approaches for the control of iron deficiency anaemia; Food and nutrition Division/ FAO/32.

Statistical hand book, (2012). District Secretariat Batticaloa District.

Tadesse, S. E., Seid, O., G/Mariam, Y., Fekadu, A., Wasihun, Y., Endris, K. \& Bitew, A. (2017). Determinants of anemia among pregnant mothers attending antenatal care in Dessie town health facilities, northern central Ethiopia, unmatched case -control study. PloS one, 12(3),e0173173.doi:10.1371/journal. pone. 0173173.

Wikramanayake, T.W. (2002). Text book of Food and Nutrition: Third Edition, reprint (second).

Zerfu, T.A, Melaku Umeta \& Kaleab Baye (2016). Dietary habits, food taboos, and perceptions towards weight gain during pregnancy in Arsi, rural central Ethiopia: a qualitative cross-sectional study. Journal of Health, Population and Nutrition35:22 DOI 10.1186/s41043-016-0059-8. 